\title{
THE USE OF THE THIOL-DISULFIDE HOMEOSTASIS AS AN INDICATOR OF OXIDATIVE STRESS IN PEDIATRIC ADENOID HYPERTROPHY PATIENTS
}

\author{
Ozdamar Kadir, ${ }^{1}$ Sen Alper, Koyuncu Ismail ${ }^{2}$ \\ ${ }^{1}$ Harran University, Medical Faculty, Department of Otorhinolaryngology \\ - Head and Neck Surgery, Şanlıurfa, Turkey \\ ${ }^{2}$ Harran University, Medical Faculty, Department of Biochemistry, Şanlıurfa, Turkey
}

Primljen/Received 02. 01. 2019. god.

Prihvaćen/Accepted 24. 02. 2019. god.

Abstract: Background: To the best of our knowledge, no study has yet focused on the association between the adenoid hypertrophy (AH) and the thiol-disulphide balance.

Objectives: The purpose of this study is to evaluate the relation between $\mathrm{AH}$ and the thiol-disulphide balance, which is used as a marker of oxidative stress (OS), by measuring its exchange using a novel technique.

Study design: Non-randomized and prospective clinical study.

Material and methods: The present study consisted of 25 patients who presented to the otolaryngology outpatient clinic of our hospital with AH. An ageand sex-matched control group was composed of 24 healthy children. The effect of AH on the thiol-disulphide balance in children was evaluated. We also evaluated the total antioxidant status (TAS), total oxidant status (TOS), oxidative stress index (OSI), ferric reducing/antioxidant power (FRAP), glutathione (GSH), lipid hydroperoxide $(\mathrm{LOOH})$ and advanced oxidation protein products (AOPP) to assess the OS status of children.

Results: The TOS was significantly higher in the AH group and the TAS was significantly higher in the control group (all $p$ values $<0.05$ ). The mean values of OSI, LOOH and AOPP were significantly higher in the AH group than the control group ( all $\mathrm{p}$ values $<0.05$ ). Native thiol and total thiol levels were lower in the AH group than those of the control group $(\mathrm{p}<0.05)$. Disulphide level and disulphide/native thiol and disulphide/total thiol ratios were higher in the $\mathrm{AH}$ group than that of the control group (all $\mathrm{p}$ values $<0.05$ ).

Conclusion: In conclusion, we observed decreased thiols with increased disulphide values in children with AH compared with the controls. Thiol/disulphide homeostasis can be used as an indicator of OS in children with $\mathrm{AH}$.

Keywords: thiol-disulphide balance, adenoid hypertrophy, oxidative stress.

\section{INTRODUCTION}

Pediatric upper airway obstruction is majorly caused by adenoid hypertrophy (AH). The most common clinical manifestations of $\mathrm{AH}$ include breathing through the mouth, blockage in nasal airways, speech with a nasal voice and obstructive sleep apnea. These patients are also at high risk for developing chronic sinusitis and middle ear infection (1). As the airways are congested, the patient may experience sleep deprivation or snoring, and sleep apnea. The manifestations are more severe for the pediatric cases, where the congested airways may lead to chronic sleep apnea and hypoxia. In more severe cases, the patient may develop pulmonary hypertension together with unilateral heart failure (majorly right-sided) $(2,3)$. There may be hypoxic metabolic changes in the cellular level; that include dissolution of cellular compartments (including the lysosomes), which leads to the discharge of free oxygen radicals.

In the homeostatic state, the human body can stabilize the free radical formation by producing antioxidants (4). There are several suggested mechanisms for oxidative stress (OS) formation. They include increased formation of ROS (reactive oxygen species) and free radicals, and diminished ability to manage the oxidative stress. As the radicals are very unstable reactants, they are likely to cause injury to the tissue by reacting with the cellular molecules such as proteins, nu- 
cleic acids, fats (specifically in the cell membrane), and carbohydrates. The purpose of antioxidant production is to prevent the possible negative effects of the free radicals. If they are not counterbalanced, the radicals may cause extensive damage, various diseases, or even death (5-9).

The thiol-disulfide homeostasis is one of the major mechanisms to prevent OS in the body (9). An automated process is used for the measurement of the thiol and disulfide levels (individually or cumulatively). With the help of this new method, the thiol-disulfide homeostasis can easily be used as an indicator of OS. The literature reports several different disorders that are associated with the thiol/disulfide balance (10-15); however, there are no studies that have examined its association with AH. Therefore, this study was planned to investigate the association of the thiol/disulfide homeostasis with $\mathrm{AH}$, through the aforementioned newly developed method. The study will mainly focus on the thiol-disulfide and pediatric AH cases. The study includes the application of several other indicators such as total antioxidant status (TAS), total oxidant status (TOS), oxidative stress index (OSI), ferric reducing/ antioxidant power (FRAP), glutathione (GSH), lipid hydroperoxide $(\mathrm{LOOH})$ and advanced oxidation protein products (AOPP)] in order to correctly determine the OS among the subjects.

\section{MATERIAL AND METHODS}

\section{The Study Sample}

The study was conducted in accordance with the principles of the Declaration of Helsinki, applicable regulatory requirements and Good Clinical Practices. This study was approved by the Ethical Committee of the Hospital (17-11-13). An informed consent form was obtained from the parents of the participants prior to being included in the study.

The study was conducted in a non-randomized and prospective manner. The experimental group (AH) consisted of 25 subjects that were chosen among the patients of the Otolaryngology Outpatient Clinic of the Hospital ( 7 females and 18 males; mean age, $5.20 \pm$ 1.70 years). The control group (C) consisted of 24 healthy children without sleep related complaints and $\mathrm{AH}$ (using flexible endoscopy) that were chosen to match the study group regarding gender and age ( 7 females and 17 males; mean age $5.25 \pm 1.75$ years).

The subject's airways were transnasally/transorally examined with a flexible endoscope. Following the endoscopic examination, the subjects were graded according to the blockage in the choanal space as follows: Grade 1, 25\% blockage; Grade 2, 25 to 50\% blockage; Grade 3, 50 to $75 \%$ blockage; Grade 4, 75 to
$100 \%$ blockage. The subjects in the experimental group had Grade 3 or 4 adenoid hypertrophy, and all of these subjects underwent transoral cold curettage adenoidectomy (with general anesthesia). The exclusion criteria were as follows: presence of nasal septal deviation, sinonasal infection, hematological disease, chronic inXammatory diseases, major craniofacial abnormalities, chromosomal syndromes, previous adenotonsillectomy or adenoidectomy; and taking any kind of medication two weeks prior to the study.

\section{Blood sample collection}

Blood samples were collected between 8 and 10 a.m. Ten milliliters of venous blood was collected from all participants into vacuum biochemistry tubes. The blood samples were centrifuged for 10 minutes at 4000 rpm; after waiting for 30-45 minutes, the sera were separated and stored at $-80{ }^{\circ} \mathrm{C}$ in Eppendorf tubes until analysis.

\section{Measurement of the Parameters}

\section{The thiol-disulfide assay}

The modified Ellman reagent was used to determine the total thiol content of the samples. The dynamic disulfide amount was calculated as follows: [(total thiol content-native thiol content)/2]. The disulfide/thiol ratio was calculated by the obtained results as stated by Erel and Neselioglu (16).

\section{The glutathione (GSH) assay}

The glutathione (GSH) level was assessed through its reaction with OPA $(1 \mathrm{mg} / \mathrm{ml}$ o-phthaldialdehyde in methanol) as per the modified technique of Koyuncu et al. (17). The obtained GSH level was used as a benchmark. The samples were assessed via the microplate reader (Spectra max M5, USA), with excitation at 345 $\mathrm{nm}$ and emission at $425 \mathrm{~nm}$. The results were expressed in $\mathrm{nmol} / \mathrm{mL}$ (for the serum) and $\mathrm{nmol} / \mathrm{g}$ (for the wet tissue).

\section{Ferric Reducing Antioxidant Power (FRAP) Assay}

The FRAP assay is a colorimetric method that measures the ferric-reducing ability of the plasma. It is easily determined through a computerized method, which makes it a practical indicator of "antioxidant power". In an acidic medium, ferric ions are reduced to ferrous form, leading to the formation of a colored ferrous-tripyridyltriazine complex (18). In the FRAP assay, the antioxidants are used as reducing agents against 
$\mathrm{Fe}(\mathrm{III})$. The ferric tripyridyltriazine complex [Fe(III), colorless] is reduced to ferrous-(2,4,6-tripyridyl-s-triazine) 2 [Ferrous(II), blue]. Subsequently, the color change is quantitatively measured through spectrophotometry at $593 \mathrm{~nm}$. The absorption values are positively correlated with the antioxidant power of the sample. Thus, the FRAP assay can be used to quantitatively measure the reducing/antioxidant power of a given sample. A mixture of $1000 \mu \mathrm{L}(100 \mu \mathrm{L}$ of sample +900 $\mu \mathrm{L}$ of diluted water) was prepared and mixed with 2 $\mathrm{mL}$ of FRAP reagent. After being thoroughly mixed, the mixture was kept in dark for $30 \mathrm{~min}$. It was subsequently analyzed with a spectrophotometer at $593 \mathrm{~nm}$. The following formula was used to calculate the FRAP value: FRAP value $\mu \mathrm{M}=[$ Abs. $($ sample $) \times$ FRAP value of $\operatorname{Std}(\mu \mathrm{M})]$ / Abs. of Std.

\section{Assay of advanced oxidation protein products}

The advanced oxidation protein products (AOPP) were spectrophotometrically determined through a modified version of the Witko, Nguyen, and Descamps-Latscha method (19). Samples were prepared as follows: $100 \mu \mathrm{L}$ of supernatant was diluted with phosphate-buffered saline (1:5), $5 \mu \mathrm{L}$ of $1.16 \mathrm{M}$ potassium iodide was then added to each tube, followed by $10 \mu \mathrm{L}$ of acetic acid two minutes later. The new mixture was analyzed with the spectrophotometer at $340 \mathrm{~nm}$ (blank reference: $1000 \mu \mathrm{L}$ of PBS, $50 \mu \mathrm{L}$ of Potassium Iodide (KI), and $100 \mu \mathrm{L}$ of acetic acid). The chloramine-T absorbance was linear at $340 \mathrm{~nm}$ within the range of $0 \mu \mathrm{mol} / \mathrm{L}$ to $100 \mu \mathrm{mol} / \mathrm{L}$. AOPP concentrations were expressed as micromoles per liter of chloramine-T equivalent.

\section{Total oxidant status (TOS) Assay}

The TOS levels were measured with the fully automated Rel Assay kit (Rel Assay Diagnostics kit, Turkey) and an autoanalyzer (Thermo Scientific Multiskan GO, ThermoFisher Scientific, Vartaa, Finland). The results were expressed in ìmol $\mathrm{H} 2 \mathrm{O} 2$ equivalent/L.

\section{Total antioxidant status (TAS) Assay}

The TAS measurements were made with the fully-automated RL0031 Rel Assay ${ }^{\circledR}$ kit (Rel Assay Diagnos-tics kit; Mega T2p, Gaziantep, Turkey) and an autoanalyzer (Thermo Scientific Multiskan GO, ThermoFisher Scientific, Vartaa, Finland). The results were expressed in micromolartrolox/L.

\section{Oxidative stress index (OSI) Assay}

OSI indicated the degree of OS by comparing the TOS and TAS values. The OSI value was calculated using the following formula: OSI (arbitrary unit) $=$ TOS (imol $\mathrm{H} 2 \mathrm{O} 2 \mathrm{Eq} / \mathrm{l}) / \mathrm{TAS}(\mathrm{mmol}$ Trolox Eq/l) $\times 100(20)$.

\section{Lipid hydroperoxide (LOOH) Assay}

Serum lipid hydroperoxide (LOOH) concentrations were spectrophotometrically measured (SpectraMax M5, Molecular Devices, USA) using automated iron oxidation-xylenol orange test (21).

\section{Statistical analysis}

The data were analyzed with SPSS for Windows, version 21.0. Descriptive statistics (mean \pm standard deviation, median, interquartile range) were used to interpret the data. The differences between the two groups were analyzed with the student's t-test and the differences between the median values were analyzed with the Mann-Withney U- and the chi-square tests. The qualitative data were analyzed using the Pearson $\chi^{2}$ test and Fisher's exact test. $p$-value $<0.05$ was considered to be statistically significant.

\section{RESULTS}

The biochemical values and demographic characteristics of all patients are presented in Table 1. It was determined that the groups were not significantly different regarding their demographic data $(\mathrm{p}>0.05)$. Compared to the control groups, the AH group's TOS values were higher and TAS values were lower $(p<0.05)$. Also, the mean OSI, LOOH and AOPP levels were found to be significantly higher among the $\mathrm{AH}$ patients ( $p<0.05$ for all variables). However, the FRAP and GSH values were lower in the AH group $(\mathrm{p}<0.05)$.

The native thiol and total thiol levels were lower and the disulfide levels were higher in the AH group $(\mathrm{AH})$, compared to the control group $(\mathrm{C})$ [native thiol = $367.1 \pm 47.5 \mathrm{lmol} / \mathrm{L}(\mathrm{AH})$ vs $476.9 \pm 63.5 \mathrm{lmol} / \mathrm{L}(\mathrm{C}), \mathrm{p}$ $<0.05$; total thiol $=412.2 \pm 48.3(\mathrm{AH}) \mathrm{lmol} / \mathrm{L}$ vs 525.8 $\pm 64.4 \mathrm{lmol} / \mathrm{L}(\mathrm{C}), \mathrm{p}<0.05 ;$ disulfide $=28.67 \pm 7.97$ $1 \mathrm{~mol} / \mathrm{L}(\mathrm{AH})$ vs $20.91 \pm 3.83 \mathrm{lmol} / \mathrm{L}(\mathrm{C}), \mathrm{p}<0.05]$. Consequently, the disulfide/native thiol and the disulfide/total thiol ratios were found to be higher for the $\mathrm{AH}$ group [disulfide/native thiol ratio $=7.96 \pm 2.59 \%(\mathrm{AH})$ vs $4.44 \pm 0.88 \%(\mathrm{C}), \mathrm{p}<0.05$; disulfide/total thiol $=$ $7.05 \pm 2.14 \%(\mathrm{AH})$ vs $4.01 \pm 0.77 \%(\mathrm{C}), \mathrm{p}<0.05]$. The difference between native thiol/total thiol ratios of the two groups was not statistically significant $(p=0.07)$. 
Table 1. Comparison of biochemical values and demographic characteristics of groups

\begin{tabular}{|l|c|c|c|}
\hline & $\begin{array}{c}\text { Patients with AH } \\
(\mathbf{n}=\mathbf{2 5})\end{array}$ & $\begin{array}{c}\text { Controls } \\
(\mathbf{n}=\mathbf{2 4})\end{array}$ & P \\
\hline Age, years & $5.20 \pm 1.70$ & $5.25 \pm 1.75$ & $0.920^{\mathrm{m}}$ \\
\hline Male gender, n (\%) & $18(72.0)$ & $17(71.0)$ & $0.928^{\mathrm{m}}$ \\
\hline TAS $(\mathrm{mmol}$ Trolox equiv./lt) & $1.2 \pm 0.23$ & $1.42 \pm 0.26$ & $0.004^{\mathrm{m}}$ \\
\hline TOS $(\mu \mathrm{mol}$ H2O2 equiv./lt) & $16.8 \pm 2.31$ & $12.16 \pm 2.77$ & $<0.001^{\mathrm{m}}$ \\
\hline OSI $(\mathrm{AU})$ & $1.42 \pm 0.25$ & $0.87 \pm 0.23$ & $<0.001^{\mathrm{m}}$ \\
\hline FRAP $(\mu \mathrm{mol} / \mathrm{l})$ & $686.1(150.0,974.0)$ & $897.5(877.2,964.2)$ & $<0.001^{\mathrm{m}}$ \\
\hline GSH $(\mathrm{nmol} / \mathrm{ml})$ & $2.34(0.64,4.75)$ & $4.98(4.87,5.36)$ & $<0.001^{\mathrm{m}}$ \\
\hline LOOH $(\mathrm{nmol} / \mathrm{l})$ & $7.21 \pm 2.34$ & $4.78 \pm 2.24$ & $0.001^{\mathrm{m}}$ \\
\hline AOPP $(\mu \mathrm{mol} /$ liter $)$ & $50.31 \pm 15.94$ & $39.29 \pm 15.27$ & $0.017^{\mathrm{m}}$ \\
\hline NATIVE THIOL $(\mathrm{SH})$ & $367,1 \pm 47,5$ & $476,9 \pm 63,5$ & $<0,001^{\mathrm{m}}$ \\
\hline TOTAL THIOL & $412,2 \pm 48,3$ & $525,8 \pm 64,4$ & $<0,001^{\mathrm{m}}$ \\
\hline DISULPHIDE $(\mathrm{SS})$ & $28,67 \pm 7,97$ & $20,91 \pm 3,83$ & $<0,001^{\mathrm{m}}$ \\
\hline \% SS/SH & $7,96 \pm 2,59$ & $4,44 \pm 0,88$ & $<0,001^{\mathrm{m}}$ \\
\hline$\%$ SS/TOTAL THIOL & $7,05 \pm 2,14$ & $4,01 \pm 0,77$ & $<0,001^{\mathrm{m}}$ \\
\hline \% SH/TOTAL THIOL & $88,97 \pm 3,74$ & $90,55 \pm 1,92$ & $0,070^{\mathrm{m}}$ \\
\hline
\end{tabular}

${ }^{\mathrm{m}}$ Mann-Whitney U-test

All variables are showed as $\mathrm{n}(\%)$ for categorical data or as mean $\pm \mathrm{SD}$ or median (minimum, maximum) for continuous data with or without a normal distribution, respectively. AH, adenoidal hypertrophy; TAS, total antioxidan status; TOS, total oxidan status; OSI, oxidative stres index; FRAP, ferric reducing/antioxidant power; GSH, glutathione; LOOH, lipid hydroperoxide; AOPP, advanced oxidation protein products.

\section{DISCUSSION}

It was observed that the disulfide/native thiol and the disulfide/total thiol ratios were significantly higher among the pediatric AH patients compared to the healthy controls. To the best of our knowledge, this is the first study to show that the thiol/disulfide homeostasis can be used as an indicator of OS among pediatric $\mathrm{AH}$ cases.

Thiols are a group of organic compounds with a sulfhydryl group (-SH) that is bound to a carbon (C) atom. The sulfhydryl groups can be oxidated to form disulfide bonds and later be reduced back to thiol groups, thus creating the thiol/disulfide homeostasis. The thiols play an important role in maintaining the oxidative condition of the body. They act as a defense mechanism against the reactive oxygen species that cause oxidative stress. Their other functions include apoptosis, detoxification, antioxidant protection, and regulation of cellular enzymatic activity $(16,22)$. Most organs and systems are sensitive to oxidative stress and redox products. Hence, the disturbance of the oxidative balance can lead to pathologies in structural and functional levels. Previously, it was only possible to measure the thiol/disulfide homeostasis. It is currently possible to separately measure both compounds with the Erel \& Neselioglu method (16). Several studies have used this method to evaluate different acute and chronic conditions $(6,9-15)$.

Insufficient thiol levels may lead to several disorders; such as bipolar disorder, atopic dermatitis, cardiovascular disorders, neurological disorders and cancer (9-15, 23-26). Thus, it is important to be able to determine the state of the thiol/disulfide balance.

The current literature indicates that the thioldisulfide homeostasis can be used as an indicator of OS for various otorhinolaryngological diseases. Simsek et al. (27) have applied this method to nasal polyposis patients. Kara et al. (24) have similarly used the disulfide/native thiol and disulfide/total thiol ratios to determine the OS state of pediatric tonsillopharyngitis patients.

It is also used to demonstrate the OS status of pediatric adenotonsillar hypertrophy patients (5). These studies were used as the basis of our research regarding the application of the said method for the pediatric $\mathrm{AH}$ patients. Gul et al. (28) have found that the serum disulfide levels had increased among adult $\mathrm{AH}$ patients. This oxidative shift is due to the obstructed airways. Several other studies also indicated that adenoid hypertrophy is positively correlated with OS. There are different possible OS indicators for AH patients. However, the thiol-disulfide homeostasis has not been previously used to evaluate the OS of children with $\mathrm{AH}$. We 
have found that the children with $\mathrm{AH}$ had an increased thiol-to-disulfide ratio, and the OS parameters had significantly increased.

It should be noted that the oxidant molecules may interact and affect the measurements. The TOS measurement is required to determine the general OS state of a patient, as it provides more information compared to the antioxidants' individual measurements (29). Indeed, the TAS measurements are more commonly used compared to individual measurements of antioxidants. In this study, we evaluated TOS, TAS, FRAP, LOOH, AOPP, OS $\propto$ and GSH levels of the experimental (AH) and control (C) groups. It was determined that among AH patients, the OS parameters (TOS, OSI, LOOH and AOPP) had increased and antioxidant parameters had decreased (GSH, TAS, FRAP). This indicates increased generation of free radicals due to increased exposure to external pathogens. These findings indicate the need for adenoidectomy among these patients to prevent OS. If left untreated, OS may lead to various diseases such as diabetes mellitus, cancer, chronic kidney disease and liver disorders.

We should be noted that our study has several limitations: the small sample size and the lack of post-adenoidectomy data. However, the initial post-adenoidectomy findings may not be reliable, as anesthesia and surgical treatment lead to operational stress. This leads to short-term changes in the OS status of the patient (30). It is also certain that the direct effects of the surgical procedure, together with the effects of tissue repair after adenoidectomy, are followed by an acute and long-lasting systemic oxidative stress. Nevertheless, the inXuence of this treatment could not be estimated as the oxidative parameters were not measured immediately after adenoidectomy. However, the samples should be collected at a later point during follow-up. Another limitation of study was the lack of information on the severity of the sleep disordered breathing.
Polysomnographic evaluation can be difficult in small children and the correlation between the severity of the sleep disordered breathing and OS parameters in small children is limited.

\section{CONCLUSION}

It was determined that the $\mathrm{AH}$ patients had decreased thiol and increased disulfide levels compared to healthy controls. Increased oxidative stress may cause serious disorders in children with AH. The thiol-disulfide homeostasis can be used as an easy method to determine the OS status of patients. These initial findings should be confirmed through further prospective studies with larger samples.
Abbreviations
OS - oxidative stress
AH - adenoid hypertrophy
TAS - antioxidant status
TOS — total oxidant status
OSI - oxidative stress index
FRAP - ferric reducing/antioxidant powe
GSH - glutathione
LOOH - lipid hydroperoxide
AOPP - advanced oxidation protein products

\section{Conflict of Interest}

No author has any potential conflict of interest.

\section{Financial Disclosure}

The work received no external financial support.

\section{Licensing}

This work is licensed under a Creative Commons Attribution 4.0 International (CC BY 4.0) License.

\title{
Sažetak
}

\section{KORIŠĆENJE TIOLDISULFIDNE HOMEOSTAZE KAO INDIKATORA OKSIDATIVNOG STRESA KOD PEDIJATRIJSKIH PACIJENATA SA ADENOIDNOM HIPERTROFIJOM}

\author{
Ozdamar Kadir, ${ }^{1}$ Sen Alper, ${ }^{1}$ Koyuncu Ismail ${ }^{2}$ \\ ${ }^{1}$ Harran University, Medical Faculty, Department of Otorhinolaryngology - Head and Neck Surgery, Şanlıurfa, Turkey \\ 2 Harran University, Medical Faculty, Department of Biochemistry, Şanlıurfa, Turkey
}

Uvod: Do sada nijedna studija se nije fokusirala na povezanosti adenoidne hipertrofije i tioldisulfidne homeostaze.

Cilj: cilj naše studije bio je da se proceni povezanost između adenoidne hipertrofije i tioldisulfid- ne homeostaze, koja se koristi kao jedan od markera oksidativnog stresa (OS), tako što smo merili njegovu raznemu koristeći novel tehniku. Dizajn studije: nerandomizovana i prospektivna klinička studija. 
Materijal i metode: U studiju je uključeno 25 pacijenata, koji su lečeni u ambulanti otorinolaringologije u našoj bolnici, a koji su bolovali od adenoidne hipertrofije. Kontrolna grupa je mečovana prema polu i godinama života, a brojala je 24 zdrava deteta. Ispitivali smo efekat adenoidne hipertrofije na balans tiol-disulfida. Takođe smo ispitivali ukupni antioksidativni status (UAS), ukupni oksidativni status (UOS), indeks oksidativnog stresa (OSI), redukujuća/antioksidativna snaga gvožđa (FRAP), glutation (GSH), lipidnu hidroperoksidazu $(\mathrm{LOOH})$ i produkte viših oksidativnih proteina (AOPP) prilikom određivanja OS statusa kod dece.

Rezultati: UOS je bio statistički značajniji u AH grupi, kao i UAK koji je bio statistički značajno viši u kontrolnoj grupi $(\mathrm{p}<0,05)$. Srednja vrednost OSI, LO-

\section{REFERENCES}

1. Izu SC, Itamoto $\mathrm{CH}$, Pradella-Hallinan M, Pizarro GU, Tufik S, Pignatari S, et al. Obstructive sleep apnea syndrome (OSAS) in mouth breathing children. Braz J Otorhinolaryngol. 2010; 76(5): 552-6.

2. Yegin Y, Çelik M, Olgun B, Koçak HE, Kayhan FT. Is ventilation tube insertion necessary in children with otitis media with effusion? Otolaryngol Pol. 2015; 69(6): 39-44.

3. Chohan A, Lal A, Chohan K, Chakravarti A, Gomber S. Systematic review and meta-analysis of randomized controlled trials on the role of mometasone in adenoid hypertrophy in children. Int J Pediatr Otorhinolaryngol. 2015; 79(10): 1599-608.

4. Serefhanoglu K, Taskin A, Turan H, Timurkaynak FE, Arslan H, Erel O. Evaluation of oxidative status in patients with brucellosis. Braz J Infect Dis. 2009; 13(4): 249-51.

5. Kiroglu AF, Noyan T, Oger M, Kara T. Oxidants and antioxidants in tonsillar and adenoidal tissue in chronic adenotonsillitis and adenotonsillar hypertrophy in children. Int J Pediatr Otorhinolaryngol. 2006; 70(1): 35-8.

6. Kundi H, Ates I, Kiziltunc E, Cetin M, Cicekcioglu H, Neselioglu $\mathrm{S}$ et al. A novel oxidative stress marker in acute myocardial infarction; thiol / disulphide homeostasis. Am J Emerg Med. 2015; 33(11): 1567-71.

7. Köksal H, Kurban S, Doğru O. Total oxidant status, total antioxidant status, and paraoxonase activity in acute appendicitis. Ulus Travma Acil Cerrahi Derg. 2015; 21(2): 139-42.

8. Yilmaz FM, Yilmaz G, Erol MF, Köklü S, Yücel D. Nitric oxide, lipid peroxidation and total thiol levels in acute appendicitis. J Clin Lab Anal. 2010; 24(2): 63-6.

9. Dinc ME, Ulusoy S, Is A, Ayan NN, Avincsal MO, Bicer C, et al. Thiol/disulphide homeostasis as a novel indicator of oxidative stress in sudden sensorineural hearing loss. J Laryngol Otol. 2016; 130(5): 447-52.

10. Kundi H, Erel Ö, Balun A, Çiçekçioglu H, Cetin M, Kiziltunç E et al. Association of thiol/disulfide ratio with syntax score in patients with NSTEMI. Scand Cardiovasc J. 2015; 49(2): 95-100.

11. Eren Y, Dirik E, Neselioglu S, Erel O. Oxidative stress and decreased thiol level in patients with migraine: cross-sectional study. Acta Neurol Belg. 2015; 115(4): 643-9.
OH i AOPP bile su statistički značajno više u AH grupi $\mathrm{u}$ odnosu na kontrolnu grupu $(\mathrm{p}<0,05)$. Nativni tiol a $\mathrm{i}$ ukupni nivoi tioldisulfida bili su viši u AH grupi u odnosu na kontrolnu grupu $(\mathrm{p}<0,05)$. Disulfidni nivoi, odnos disulfid/nativni tiol, kao i disulfid/ukupni tiol odnos je bio statistički značjano viši u AH grupi u odnosu na svoju kontrolnu grupu $(\mathrm{p}<0,05)$.

Zaključak: U zaključku možemo istaći da smo u ovoj studiji dobili rezultate koji ukazuju na snižen nivo tiola, kao i povećan nivo disulfidnih vrednosti kod dece sa AH u odnosu na svoje kontrole. Tiol/disulfid homeostaza može biti indikator oksidativnog stresa kod dece sa AD.

Ključne reči: tiol-disulfid balas, adenoidna hipertrofija, oksidativni stres.

12. Ergin M, Cendek BD, Neselioglu S, Avsar AF, Erel O. Dynamic thiol-disulfide homeostasis in hyperemesis gravidarum. J Perinatol. 2015; 35(10): 788-92.

13. Karadag-Oncel E, Erel O, Ozsurekci Y, Caglayik DY, Kaya A, Gozel MG, et al. Plasma oxidative stress and total thiol levels in Crimean-Congo hemorrhagic fever. Jpn J Infect Dis. 2014; 67(1): 22-6.

14. AltinelAcoglu E, Erel O, Yazilitas F, Bulbul M, Oguz MM, Yucel H, et al. Changes in thiol/disulfide homeostasis in patients with juvenile idiopathic arthritis. Pediatr Int. 2018; 60(6): 593-6.

15. Uysal P, Avcil S, Neşelioğlu S, Biçer C, Çatal F. Association of oxidative stress and dynamic thiol-disulphide homeostasis with atopic dermatitis severity and chronicity in children: a prospective study. Clin Exp Dermatol. 2018; 43(2): 124-30.

16. Erel O, Neselioglu S. A novel and automated assay for thiol/disulphide homeostasis. Clin Biochem. 2014; 47(18): 326-32.

17. Koyuncu I, Kocyigit A, Gonel A, Arslan E, Durgun M. The Protective Effect of naringenin-oxime on cisplatin-induced toxicity in rats. Biochem Res Int. 2017; 2017: 9478958.

18. Benzie IFF, Strain JJ. The Ferric Reducing Ability of Plasma (FRAP) as a Measure of Antioxidant Power: The FRAP Assay. Analy Biochem. 1996; 239(1): 70-6.

19. Witko V, Nguyen AT, Descamps-Latscha B. Microtiter plate assay for phagocyte derived taurine-chloramines. J Clin Lab Anal. 1992; 6(1): 47-53.

20. Alp R, Selek S, Alp SI, Taskin A, Kocyigit A. Oxidative and antioxidative balance in patients of migraine. Eur Rev Med Pharmacol Sci. 2010; 14(10): 877-82.

21. Arab K, Steghens JP. Serum lipid hydroperoxides measurement by an automated xylenol orange method. Anal Biochem. 2004; 325(1): 158-63.

22. Thomas JA, Poland B, Honzatko R. Protein sulfhydryls and their role in the antioxidant function of protein S-thiolation. Arch Biochem Biophys. 1995; 319(1): 1-9.

23. Demirseren DD, Cicek C, Alisik M, Demirseren ME, Aktaş A, Erel O. Dynamic thiol/disulphide homeostasis in patients with basal cell carcinoma. Cutan Ocul Toxicol. 2017;36(3): 278-82.

24. Kara SS, Erel O, Demirdag TB, CuraYayla BC, Gulhan B, NeseliogluS, et al. Alteration of thiol-disulphide homeo- 
stasis in acute tonsillopharyngitis. Redox Rep. 2017; 22(5): 205-9.

25. Bektas H, Vural G, Gumusyayla S, Deniz O, Alisik M, Erel O. Dynamic thiol-disulfide homeostasis in acute ischemic stroke patients. Acta Neurol Belg. 2016; 116(4): 489-94.

26. Hanikoglu F, Hanikoglu A, Kucuksayan E, Alisik M, Gocener AA, Erel O, et al. Dynamic thiol/disulphide homeostasis before and after radical prostatectomy in patients with prostate cancer. Free Radic Res. 2016; 50(sup1): S79-S84.

27. Şimşek E, Erel O, Bicer CK, Çarlıoğlu A. A novel method for determining the relation between nasal polyposis and oxidative stress: the thiol/disulphide homeostasis. Acta Otolaryngol. 2016; 136(11): 1180-3.

28. Gul F, Muderris T, Yalciner G, Mise HI, Canan Y, Babademez MA, et al. A novel method for evaluation of oxidative stress in children with OSA. Int J Pediatr Otorhinolaryngol. 2016; 89: 76-80.

29. Erel O. A new automated colorimetric method for measuring total oxidant status. Clin Biochem. 2005; 38(12): 1103-11.

30. Allaouchiche B, Debon R, Goudable J, Chassard D, DuXo F. Oxidative stress status during exposure to propofol, sevoXurane and desXurane. Anesth Analg. 2001; 93(4): 981-5.

\section{Correspondence to/Autor za korespondenciju}

Assit. Prof. Kadir Özdamar

Harran Tip Fakültesi Araştırmave Uygulama Hastanesi

MardinYolu 22 Km Osmanbey Kampüsü, ŞANLIURFA

phone: 05336259180

E-mail: drkadirozdamar@hotmail.com 